\title{
A brain bank for Sri Lanka
}

\section{K R D De Silva ${ }^{1}$, S K Shankar ${ }^{2}$, A Mahadevan $^{2}$ and P R Dodd ${ }^{3}$}

Our ageing population has a high prevalence of neurodegenerative diseases, and infectious diseases of the nervous system are emerging in Asia. Extrapolation from animal research to humans has the disadvantage of species differences in anatomy, physiology, biochemistry, and genetics. The systematic collection and cryopreservation of human brains at autopsy in "brain banks" is a useful resource [1,2]. Standardised protocols for brain retrieval, dissection, cryopreservation, and distribution have been established. Brain bank networks in the USA and Europe facilitate data and specimen exchange, and make high quality tissue available [3].

The Sri Lankan population has distinctive demographic and ethnic features which may modulate the presentation of neurological disorders. Life expectancy of 74.1 years is the highest in the region. The over- 60 population (currently 9.6\%) is expected to increase rapidly to reach $13 \%$ in 2010 and $21 \%$ in 2025. To develop effective management strategies, it is essential to have baseline scientific data on nervous system disorders. Due to its cultural and religious practices, Sri Lanka is in a unique position to obtain brain tissue for research.

\section{Potential pitfalls}

In animal models, the investigator has control over choice of species, gender and genetic homogeneity (inbred animals). With human material patient-related variables play crucial roles, from administrative, legal, and ethical issues to antemortem and postmortem events. Conducting an autopsy and collecting the brain can be delayed by the need to contact relatives for written consent and availability of suitable professional and technical staff. It is optimal to collect tissue within 6 hours of death, but brain tissue collected 48 hours or more postmortem can be useful for many studies [4]. Intact and biologically active nucleic acids and proteins have been obtained from brains collected after 72 hours [5].

Diseased brains can be compared with matched controls. Factors such as antemortem nutritional status, agonal state, postmortem interval etc, may influence the results, and must be controlled [6]. Tissue integrity must be well maintained. The interval between death and freezing of the tissue affects the preservation of some neuropeptides and catecholamines [7]. Terminal agonal state can influence some transcripts and proteins [8]. Cerebrospinal fluid is a useful resource, and many brain banks collect it. DNA is well preserved in autopsy brain [9]. High molecular weight DNA can be extracted from cerebral cortex 20 days postmortem, whereas it degrades in blood and kidney within a week [9]. Although RNA is labile in many tissues, it is quite stable in frozen brain [4].

Slow freezing of tissues reduces osmotic shock and ice crystal formation, preserving biochemical and structural integrity [10]. Hypoxia antemortem increases lactate and lowers brain $\mathrm{pH}$, which can fragment RNA and some proteins [11]. Coma prolonged for more than 24 hours leads to loss of RNA. Tissue $\mathrm{pH}$ does not vary across

\footnotetext{
${ }^{1}$ Department of Anatomy, Faculty of Medical Sciences, University of Sri Jayewardenepura, Nugegoda, Sri Lanka, ${ }^{2}$ Human Brain Bank, National Institute of Mental Health and Neurosciences, Bangalore, India, and ${ }^{3}$ School of Molecular and Microbial Sciences, University of Queensland, Brisbane, Australia.
}

Correspondence: KRDDS, e-mail: <ranilds@sltnet.lk>. Competing interests: none declared. 
brain regions and is stable following death and during storage [12]. How circadian fluctuation affects brain collected at autopsy is not clear [13]

Ontogeny, gender, ethnicity, and drug use may affect neurochemical variables $[4,14]$. Lack of suitable cases may limit analysis of normal and diseased brain. This problem can be addressed by forming national and international networks. Brains from tropical countries may be compared with those from high latitudes. In brains from Indian patients with Parkinson's diseases the numbers of pigmented neurons were nearly $40 \%$ less than those in brains from the west, yet there is low prevalence of the disease in India [15]. 82 cases of Creutzfeldt Jacob disease were recorded at the Bangalore Brain Bank in 32 years, some in vegetarians. This gives a different context to variant-CJD in the UK.

Donor options and eligibility. The Transplantation of Human Tissues Act of Sri Lanka allows donation and removal of tissues for therapeutic, scientific, educational, and research purposes. Persons may express their willingness during life to be potential donors after death. A signed donor card is a legal document, but consent should be sought from close relatives. In the absence of a donor card, consent must be obtained from the spouse or next of kin. The relatives should be assured that brain removal does not result in disfigurement.

The brain is first hemisected, and one half fixed in formalin for pathomorphological studies and to establish diagnosis. The other half is sliced in the coronal plane and frozen, or dissected samples cryopreserved in isotonic sucrose at $-80^{\circ} \mathrm{C}$. Tests are done for HIV, HBVsAg, and HCV. Research studies must have ethics committee approval and must also conform to the ethical standards of the brain bank. Tissues and fluids at the bank are a public resource. The brain bank is a national research facility, not a profit-making organisation. A nominal processing charge may be levied as approved by the governing council, to meet maintenance costs.

\section{Conclusion}

Sri Lanka should establish a human brain bank and make a significant contribution to neuroscience. A proactive approach by the government in providing funds and facilities will help establish the country's eminence in neuroscience.

\section{References}

1. Tourtellotte WW, Cohenour RC, Raj J. The NINCDS/ NIMH human neurospecimen bank. NeuropsychoPharmacology, volume 2. In: Deniker P, Radonco-Thomas C, Villaneuve A (eds). Proceedings of the tenth congress of the Collegium Internationale Neuro-Psychopharma-Cologicum. Pergamon Press, Washington: 1978: 1593-95.

2. Bird ED, Vonsattel JP. The development of a brain bank. Journal of Neural Transmission 1993; 39: 17-23.
3. Cruz-Sanchez FF, Ravid R. European Brain Bank for neurological and psychiatric disorders. Declaration of Intent for the Concerted Action Programme of the Commission of the European Communities.

4. Hynd MR, Lewohl JM, Scott HL, Dodd PR. Biochemical and molecular studies using human autopsy brain tissue. Journal of Neurochemistry 2003; 85: 543-62.

5. Bahn S, Augood SJ, Rayan M, Standaert DG, Starkey M, Emson PC. Gene expression profiling in the postmortem human brain - no cause for dismay. Journal of Chemical Neuroanatomy 2002; 22: 79-94.

6. Alafuzoff I, Winbald B. How to run a brain bank: potentials and pitfalls in the use of human post-mortem brain material in research. Journal of Neural Transmision 1993; 39(Suppl 1): 235-43.

7. Arranz B, Blennow K, Ekman R, Erikson A, Mansson JE, Marcusson J. Brain monoaminergic and neuropeptidergic variations in human ageing. Journal of Neural Transmision 1996; 103: 101-15.

8. Yasojima K, McGeer EG, McGeer PL. High stability of mRNAs post-mortem and protocols for their assessment by RT-PCR. Brain Research. Brain Research Protocols 2001; 8: 212-18.

9. Lahiri DK, Ge Y. Electrophoretic mobility shift assay for the detection of specific DNA - protein complex in nuclear extracts from cultured cells and frozen autopsy human brain tissue. Brain Research. Brain Research Protocols 2000; 5: 257-65.

10. Dodd PR, Hardy JA, Baig FB, Kidd AM, Bird ED, Watson WEJ, Johnston GAR. Optimization of freezing, storage, and thawing conditions for the preparation of metabolically active synaptosomes from frozen rat and human brain. Neurochemical Pathology 1986; 4: 177-98.

11. Paschen W, Djuricic B, Mies G, Schmidt-Kastner R, Linn F. Lactate and $\mathrm{pH}$ in the brain: association and dissociation in different pathophysiological states. Journal of Neurochemistry 1987; 48: 154-9.

12. Johnston NL, Cervenak J, Share AD, Torrey EF, Yolken $\mathrm{RH}$, Cereunak J. Multivariant analysis of RNA levels from postmortem human brains as measured by three different methods of RT-PCR. Journal of Neuroscience Methods 1997; 77: 83-92.

13. Mikami H, Terazawa K, Takatori T, Tokudome S, Tsukamoto T, Haga K. Estimation of time of death by quantification of melatonin in corpses. International Journal of Legal Medicine 1994; 107: 42-51.

14. McLeman ER, Warsh JJ, Ang L, et al. The human nucleus accumbens is highly susceptible to G protein down regulation by methamphetamine and heroin. Journal of Neurochemistry 2000; 74: 2120-26.

15. Muthane U, Yasha TC, Shankar SK. Low numbers and no loss of melanised migral neurons with increasing age in normal human brains from India. Annals of Neurology 1998; 43: 283-7. 